\title{
Sequential interleukin 2 and pembrolizumab use in progressive multifocal leukoencephalopathy
}

Christoph Mahler, MD,* Michael Andrews, MD,* Sian M. Henson, PhD, and Sharmilee Gnanapavan, MD, PhD

Neurol Neuroimmunol Neuroinflamm 2020;7:e756. doi:10.1212/NXI.0000000000000756

Progressive multifocal leukoencephalopathy (PML) secondary to John Cunningham (JC) virus infection remains as yet an untreatable viral infection. Plasmapheresis, adoptive T-cell therapyies, and immune reconstitution strategies have all been used with variable success. Cortese et al. ${ }^{1}$ showed that pembrolizumab, a programmed cell death protein-1 (PD-1) checkpoint inhibitor, increases $\mathrm{CD}^{+}$and $\mathrm{CD}^{+}$activities and thereby reduces JC viral load. Five of their 8 patients did well, but the remainder, despite effective PD- 1 suppression, failed to establish an anti-JC virus T-cell response. Recently, Kuepper et al. ${ }^{2}$ published a case of primary immunodeficiency with PML who demonstrated a dramatic reduction in PD-1 expression with pembroluzimab, but the patient still died.

Here, we propose that treating the initial lymphopenia before targeting PD1 expression on $\mathrm{T}$-cells is more effective in clinical outcomes. We used the IL-2 therapy to boost the T-cell $\mathrm{CD} 4 / \mathrm{CD} 8$ populations before treatment with pembrolizumab. ${ }^{3}$

\section{Case 1}

A 33-year-old woman presented with progressive cerebellar syndrome on a 4-month history of stage IV diffuse large cell B lymphoma (DLBCL, stage IV) and chemotherapy with rituximab-cyclophophamide, doxorubicin hydrochloride, pncovin, prednisolone (6 cycles) and intrathecal methotrexate ( 4 cycles). Over the course of 2 weeks, she developed progressive gait ataxia, with multiple falls, and dysarthria. A brain MRI revealed a T2/fluidattenuated inversion recovery hyperintense lesion in the cerebellar peduncle, and PML was confirmed after brain biopsy with JC virus-positive oligodendrocytes (SV40 staining and RNASeq) and CSF (JC virus DNA 449 copies/mL). Initially, the patient received granulocyte-colony stimulating factor without improvement in $\mathrm{CD}^{+}$and $\mathrm{CD} 8^{+}$counts. Subsequently, IL-2 was commenced as a subcutaneous (s.c.) injection (IL-2: 50,000 units/ $\mathrm{m}^{2}$, followed by 1 million units $/ \mathrm{m}^{2}$ maintenance dose, figure, A). After 5 days, IL-2 was switched to IV infusions (same dose). During the initial applications, an infusion reaction with increased temperatures and confusion occurred, and no severe side effects were observed. A total of 19 doses of IL-2 followed by one dose of pembrolizumab (200 mg, iv) were administered based on elevated PD- $1+\mathrm{CD}^{+} 70 \%$ and PD- $1+\mathrm{CD} 8^{+} 79 \%$ compared with agematched controls of PD- $1+\mathrm{CD} 4^{+} 8 \%$ and PD- $1+\mathrm{CD} 8^{+} 10 \%$. On treatment, her T-cell counts increased (CD4 ${ }^{+}$before: $24 / \mu \mathrm{L}$, after: $77 / \mu \mathrm{L}$; CD $8^{+}$before: $4 / \mu \mathrm{L}$, after: $\left.89 / \mu \mathrm{L}\right)$ and her JC virus titer decreased to 98 copies/mL. Her MRI (figure, C) and her clinical symptoms stabilized; however, unfortunately, her original lymphoma reoccurred a month later, and a decision was made not to retreat.

\author{
Correspondence \\ Dr. Gnanapavan \\ sharmilee.gnanapavan@nhs.net
}

*These authors contributed equally to this work.

From the Department of Neurosciences (C.M., M.A., S.G.), the Royal London Hospital, Barts Health NHS Trust; and William Harvey Research Institute (S.M.H., S.G.), Barts \& the London School of Medicine and Dentistry, Queen Mary University of London, Charterhouse Square, London, United Kingdom.

Go to Neurology.org/NN for full disclosures. Funding information is provided at the end of the article.

The Article Processing Charge was funded by the authors.

This is an open access article distributed under the terms of the Creative Commons Attribution-NonCommercial-NoDerivatives License 4.0 (CC BY-NC-ND), which permits downloading and sharing the work provided it is properly cited. The work cannot be changed in any way or used commercially without permission from the journal. 




Days from diagnosis of PML

C

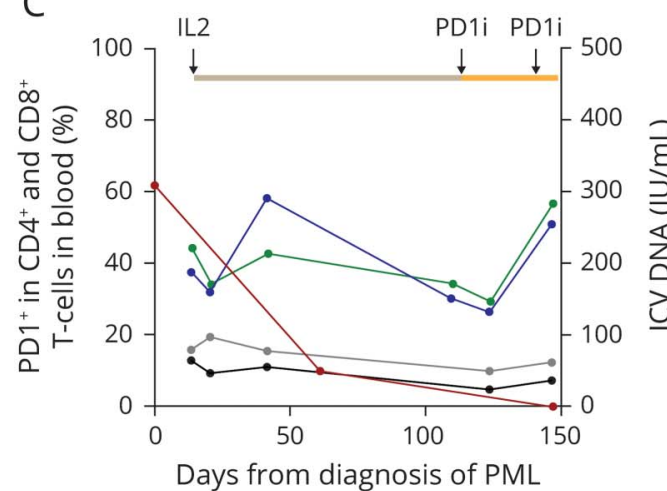

D. Months to diagnosis of PML



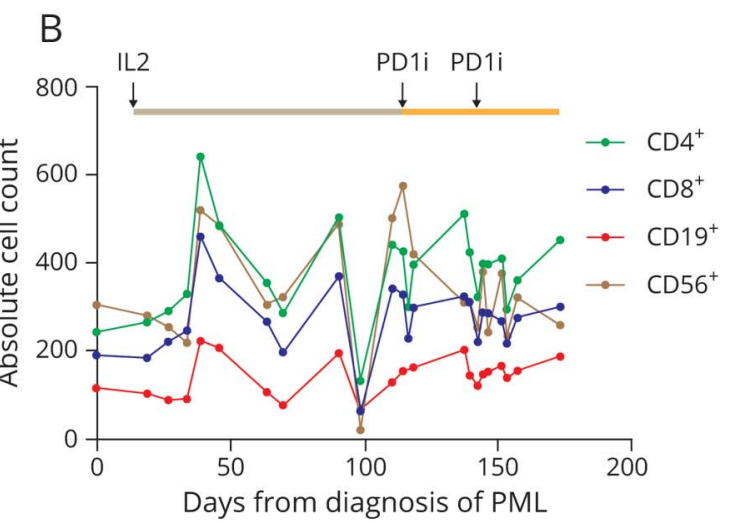

$\rightarrow \mathrm{PD} 1^{+} \mathrm{CD} 4^{+}$

$\rightarrow \mathrm{PD}^{+} \mathrm{CD} 8^{+}$

$\rightarrow \mathrm{CPD}^{+} \mathrm{CD} 4^{+}$

$\rightarrow \mathrm{CPD}^{+} \mathrm{CD} 8^{+}$

Shown is the percentage of PD-1+ in CD4 ${ }^{+}$and CD8 ${ }^{+}$T-cells in blood and the JC virus DNA titer in CSF (A and B) and lymphocyte subpopulations in blood (case 1 : A, case 2: B) (C) case 2 PD-1 + \% in blood vs age-matched control (control PD-1+) and JC virus DNA titer in the CSF. Evolution of the PML lesion in MRI (D) case 1, (E) case 2, top: T2/FLAIR, middle: T2/FLAIR lesion area pseudocolored in yellow, differential increase (red), differential reduction (green), bottom: B1000 DWI. Treatment bar: brown for IL2 and yellow for PD1. *Marks drop in lymphocyte subpopulations in case 2 secondary to dose escalation of IL-2 to 2.07 million units $/ \mathrm{m}^{2}$. JC = John Cunningham; PD-1 = programmed cell death protein-1; PML = Progressive multifocal leukoencephalopathy.

\section{Case 2}

A 60-year-old man presented with a frontal lobe syndrome, cognitive impairment, and personality change subsequent to treatment with 6 cycles of R-CHOP for DLBCL (stage IIIS) diagnosed 12 months before presentation. MRI demonstrated a progressive $\mathrm{PML}$ lesion in the frontal lobe (figure, $\mathrm{D}$ ), and the
CSF JCV DNA titer was 309 copies $/ \mathrm{mL}$. Treatment was initially commenced on daily s.c. IL-2: 50,000 units $/ \mathrm{m}^{2}$ for 5 days and subsequently increased to 1 million units $/ \mathrm{m}^{2}$. On dose increase, he developed fevers, confusion, and tremors, which resolved with dose reduction back down to 50,000 units $/ \mathrm{m}^{2}$ and periinfusion paracetamol and chlorphenamine. After 8 days, the route of administration was switched to i.v., then 
escalated to 1 million units $/ \mathrm{m}^{2}$ and later to 2.07 million units/ $\mathrm{m}^{2}$. The latter resulted in a sudden drop in lymphocyte subsets, and the dose was quickly reduced back down to 1 million units $/ \mathrm{m}^{2}$ leading to recovery (figure, B). A total of 99 doses of IL- 2 were given, followed by 2 doses of pembrolizumab (175 mg, iv). JC virus DNA levels decreased and were undetectable by the end of treatment (figure, C). Lymphocyte populations increased $\left(\mathrm{CD}^{+}\right.$before: $245 / \mu \mathrm{L}$, after: $398 / \mu \mathrm{L}$; $\mathrm{CD}^{+}$before: $192 / \mu \mathrm{L}$, after: $300 / \mu \mathrm{L}$; figure, $B)$, and MRI showed stabilization of the PML lesion (figure, D). On discharge, he was fully independent for all activities of daily living.

PML in cases of significant lymphopenia is particularly difficult to manage. The overall immune response is hampered because of the deficient immune cell interactions and a failure to mount an effective T-cell immune response. ${ }^{4,5}$ Using IL-2 first to boost the native lymphocyte population is a key strategy to mounting an effective immune response to JC virus. ${ }^{3}$ This can subsequently be consolidated using a PD-1 antagonist, such as pembrolizumab, to maintain the activity. To our knowledge, this is the first report of a combined treatment with IL-2, followed by pembrolizumab for PML.

Indeed, the $\mathrm{CD} 4^{+}$and $\mathrm{CD}^{+}$profiles fluctuate with the IL-2 treatments, as do their PD1 expression, suggesting that the artificial boosting of these cell subsets is closely related to the individual injections. Interestingly, there was also favorable improvement of other immune subsets, including CD19 and CD56; CD56 being more robust. Data on the relative distribution and activity of different immune cells are unknown, with $\mathrm{CD}^{+}$lymphopenia being considered critical in PML emergence. ${ }^{6}$ Moreover, sustained expression of PD-1 on their cell surfaces has been linked to T-cell exhaustion. ${ }^{7}$ It is therefore critical to deploy a dual strategy not only stimulating the intrinsic lymphocyte pool but also sustaining their activity. We found that the PD1 expression in the age-matched healthy controls was much lower and less prone to variation (figure, $\mathrm{C}$ ). Despite an initial downward trend in PD-1 expression in case 1 after pembroluzimab, the levels did increase again. There is a growing appreciation that although PD-1/PD-L1 therapy can result in dramatic therapeutic responses, treatment is only effective in a subset of patients, and many patients are only partial responders. Indeed, some patients do not respond to initial therapy, whereas others, despite showing a robust initial response to therapy, go on to develop progressive disease. The mechanisms for this resistance are being uncovered, but it is becoming clear that a patient's individual environmental and genetic factors, together with previous treatments create an evolving therapeutic environment that may be in play here. ${ }^{8}$

\section{Acknowledgment}

The authors would like to thank Professor David Baker, Queen Mary University of London for his helpful comments.

\section{Study funding}

No targeted funding reported.

\section{Disclosure}

C. Mahler, M. Andrews, and S.M. Henson report no disclosures related to this study. S. Gnanapavan: Honoraria/ speaker fees from Biogen Idec, Novartis, Merck, Roche, Teva and Neurodiem; and grant funding for UK MS Society, NMSS, Genzyme, Merck, and Takeda. Go to Neurology.org/ NN for full disclosures.

\section{Publication history}

Received by Neurology: Neuroimmunology \& Neuroinflammation December 11, 2019. Accepted in final form April 6, 2020.

Appendix Authors

\begin{tabular}{lll}
\hline Name & Location & Contribution \\
\hline $\begin{array}{l}\text { Christoph } \\
\text { Mahler, MD }\end{array}$ & $\begin{array}{l}\text { Royal London } \\
\text { Hospital, United } \\
\text { Kingdom }\end{array}$ & $\begin{array}{l}\text { Data collection, drafting, and } \\
\text { revising the manuscript }\end{array}$ \\
\hline $\begin{array}{l}\text { Michael } \\
\text { Andrews, MD }\end{array}$ & $\begin{array}{l}\text { Royal London } \\
\text { Hospital, United } \\
\text { Kingdom }\end{array}$ & $\begin{array}{l}\text { Data collection, drafting, and } \\
\text { revising the manuscript }\end{array}$ \\
\hline $\begin{array}{l}\text { Sian M. } \\
\text { Henson, PhD }\end{array}$ & $\begin{array}{l}\text { Queen Mary } \\
\text { University of London, Kingdom }\end{array}$ & $\begin{array}{l}\text { Laboratory analysis and critical } \\
\text { comments during the } \\
\text { manuscript revision }\end{array}$ \\
\hline $\begin{array}{l}\text { Sharmilee } \\
\text { Gnanapavan, } \\
\text { MD, PhD }\end{array}$ & $\begin{array}{l}\text { Royal London } \\
\text { Hospital, United } \\
\text { Kingdom }\end{array}$ & $\begin{array}{l}\text { Study supervision, clinical care } \\
\text { for the patient, and critical } \\
\text { comments during the } \\
\text { manuscript revision }\end{array}$ \\
\hline
\end{tabular}

\section{References}

1. Cortese I, Muranski P, Enose-Akahata Y, et al. Pembrolizumab treatment for progressive multifocal leukoencephalopathy. N Engl J Med 2019;380:1597-1605.

2. Kupper C, Heinrich J, Kamm K, et al. Pembroluzimab for progressive multifocal leukoencephalopathy due to primary immunodeficiency. Neurol Neuroimmunol Neuroinflamm 2019;6:e628. doi: 10.1212/NXI.0000000000000628.

3. Gascó AF, Vericat JM, Albir MC, et al. CP-070 Interleukin-2 treatment of two patients with multifocal progressive leukoencephalopathy associated with hiv infection. Eur J Hosp Pharm 2017;24:A31.

4. Durali D, de Goër Herve MG, Gasnault J, Taoufik Y. B cells and progressive multifocal leukoencephalopathy: search for the missing link. Front Immunol 2015;6:241.

5. Taoufik Y, de Goër Herve MG. Editorial: immune control of JC virus infection and immune failure during progressive multifocal leukoencephalopathy. Front Immunol 2017;8:1646.

6. Berger JR, Pall L, Lanska D et al. Progressive multifocal leukoencephalopathy in patients with HIV infection. J Neurovirol 1998;4:59-68.

7. Tumeh PC, Harview CL, Yearley JH et al. PD-1 blockade induces responses by inhibiting adaptive immune resistance. Nature 2014;515:568-571.

8. Nowicki TS, Hu-Lieskovan S, Ribas A. Mechanisms of resistance to PD-1 and PD-L1 blockade. Cancer J 2018;24:47-53. 


\title{
Neurology $^{\odot}$ \\ Neuroimmunology \& Neuroinflammation
}

\author{
Sequential interleukin 2 and pembrolizumab use in progressive multifocal \\ leukoencephalopathy \\ Christoph Mahler, Michael Andrews, Sian M. Henson, et al. \\ Neurol Neuroimmunol Neuroinflamm 2020;7; \\ DOI 10.1212/NXI.0000000000000756
}

This information is current as of May 20, 2020

\section{Updated Information \& Services}

References

Subspecialty Collections

Permissions \& Licensing

\section{Reprints}

including high resolution figures, can be found at:

http://nn.neurology.org/content/7/4/e756.full.html

This article cites 8 articles, 1 of which you can access for free at: http://nn.neurology.org/content/7/4/e756.full.html\#\#ref-list-1

This article, along with others on similar topics, appears in the following collection(s):

All Immunology

http://nn.neurology.org//cgi/collection/all_immunology MRI

http://nn.neurology.org//cgi/collection/mri

Information about reproducing this article in parts (figures,tables) or in its entirety can be found online at:

http://nn.neurology.org/misc/about.xhtml\#permissions

Information about ordering reprints can be found online: http://nn.neurology.org/misc/addir.xhtml\#reprintsus

Neurol Neuroimmunol Neuroinflamm is an official journal of the American Academy of Neurology.

Published since April 2014, it is an open-access, online-only, continuous publication journal. Copyright

Copyright (C) 2020 The Author(s). Published by Wolters Kluwer Health, Inc. on behalf of the American

Academy of Neurology.. All rights reserved. Online ISSN: 2332-7812.



